\title{
Implementation of the Mandatory Minimum Sanctions for Children Abuser in the Surabaya High Court Decision Number 763/Pid.Sus/2020/PT SBY
}

\author{
Andy Wijaya ${ }^{1}$ Ade Adhari $^{1 *}$ \\ ${ }^{1}$ Faculty of Law, Tarumanagara University, Jl. Letjen. S. Parman No. 1, West Jakarta, DKI Jakarta 11440, Indonesia \\ ${ }^{*}$ Corresponding author, Email: adea@fh.untar.ac.id
}

\begin{abstract}
Children are the next generation of the Indonesian nation in the future, but children need legal protection because children are creatures that are vulnerable to all threats that can disturb both physically and psychologically. The government made Law Number 35 of 2014 concerning Child Protection with special mandatory minimum sanction as a form of child protection in the form of a written law. How is the application of mandatory minimum sanctions against perpetrators of crimes against children in the Surabaya High Court Decision Number 763 / PID.SUS / 2020 / PT.SBY? This research is applied with a normative research method by examining secondary legal materials, documentary studies, and the analysis method used is deductive by examining problems by looking for major premises and minor premises. This research discusses why mandatory minimum sanctions should be applied to article 82 of the Child Protection Law in the High Court decision Number 763 / Pid.Sus / 2020 / PT SBY to impose sanctions on the defendant Ali Shodiqin.
\end{abstract}

Keywords: Child protection law, judicial power, sexual harassment, mandatory minimum sanctions, conventions, legal security

\section{INTRODUCTION}

The definition of a child according to Law Number 35 of 2014 concerning Child Protection is an individual who is not yet 18 years old, the Child Protection Law also explains that a fetus that is still in the womb is also categorized as a child. Children have important functions for a country, one of which is as the nation's next generation in order to realize the goals of the Indonesia to become a developed country.[1]

In the reality, children are individuals who are vulnerable to becoming victims of various kinds of actions that cause mental, social and physical harm. The nature of children as social beings who have weak physical, mental and immature forms and are easily affected by the circumstances around the environment from where the child grows and develops until he becomes an adult. Therefore, children need serious attention by those who are responsible for children, in the form of family, teachers and government. The government as the party responsible for the protection of children's human rights provides protection efforts in the form of institutions as bodies that guarantee the implementation of children's rights in the form of the Indonesian Child Protection Commission (KPAI) and the Indonesian National Police (POLRI), as well as in the form of law enforcement. in the form of the formation of laws relating to children.

One of the laws established by the government is Law Number 35 of 2014 concerning Child Protection. Based on article 1 number 2 of Law Number 35 Year 2014 concerning Child Protection, the function of the Child Protection Law is to guarantee and protect children and their rights so that they can live, grow, develop and participate optimally in accordance with human dignity and get self-protection from acts of violence and discrimination. Forms of Protection of Children's Rights based on Law Number 35 of 2014 concerning Child Protection regulates the provisions of mandatory minimum sanctions in the formulations of offenses.

In Law Number 35 of 2014 concerning Child Protection, there are 14 articles that contain criminal elements stipulated in the Child Protection Law, among these 14 articles there are 4 articles that apply a mandatory minimum sanctions pattern in imposing criminal sanctions against perpetrators who violate the provisions of 4 articles among others, Article 81 concerning Intercourse, Article 82 concerning Obscene Acts, Article 83 concerning Child Trafficking and Article 89 concerning Involving Children with Narcotics. Mandatory minimum sanctions is a criminal system that has a minimum sanction limit with a certain time. 
These mandatory minimum sanctions can be indicated by the term indicating the application of the lowest sanction. This is indicated by the phrase "at least" in the article in a particular statutory regulation. The formulation of the minimum criminal code that applies in Indonesia is regulated in Article 103 of the Criminal Code (KUHP) which states that only laws outside the Criminal Code have the authority to regulate a mandatory minimum sanctions system. The minimum criminal principle is specifically applied to certain offenses which are considered to be very detrimental, dangerous or disturbing to social life in society. The formulation of limits on the validity period of the application of mandatory minimum sanctions sanctions is adjusted to the nature and weight of the offense in question to the victim. [2]

Mandatory minimum sanctions is not owned by all laws that are specific in nature including a mandatory minimum sanction pattern. One of the laws that has a mandatory minimum sanctions system for certain offenses is Law No. 35 of 2014 concerning Child Protection. The consequence of enforcing a mandatory minimum sanctions system is that there is an obligation for a judge to decide on a case with a limit that may give rise to legal consequences in the form of the determination of sanctions not less than the minimum number of articles of a statutory law used as the basis for the consideration of the Panel of Judges to impose sanctions on defendant.

In reality, some of the judges ignore to sanctions the serious crimes based on the mandatory minimum sanctions. The example of that case is Ali Shodiqin case.

This case began on May 9, 2019 at around 10:00 WIB (West Indonesia Time), a psychologist conducted a psychological examination of 21 children at the SMP Lab. School Surabaya.

The results of the psychological examination found 2 children who were also victims of abuse, namely M. Rizky Wisnu W, 14 years old and M. Risky Putra R, 14 years old. Furthermore, on May 10, 2019 at around 10.00 WIB.

Psychologists conducted psychological examinations on 20 children at SMP Lab. School Surabaya and from the results of the psychological examination found 1 child who was also a victim of sexual immorality, namely Valent Babyanjaya, aged 14.

The results of the examination led to several parents asking about the incident to their children and one of them was the parents of Mustafa Langit Karya Sentana, who apparently experienced violence by the defendant Ali Shodiqin, then a report was made of the incident to the police.

\subsection{Related Works}

This paper presents several criminal law theories related to Children Sexual Harassment criminal cases which are appointed into several categories.

\subsubsection{Law policy theory}

Basically, law has a character that always follows changes adapted to the times, culture, social, politics and even the environment in society. The nature of the law which often undergoes changes and reforms occurs as a result of the function of the law as an answer to all challenges and guidance of society in the present. Legal reform is carried out in order to create a better law because it is in accordance with the needs of society in the present so as to achieve prosperity, order, security, and peace in people's lives. Various aspects of policies that become the background for reforming criminal law are social policies, criminal policies and law enforcement policies. ) The essence of legal reform is an approach that has a policy orientation and an approach that has a value orientation. It can be concluded that the reform of criminal law is one part of the political policy of criminal law. The policy to establish useful criminal law regulations cannot be separated from the goal of overcoming crime, so criminal law policy is also part of criminal politics. ) From the point of view of criminal politics, the politics of criminal law are related to the notion of policies for dealing with crime.

\subsubsection{Requirement of crime theory}

Sudarto said "the first element of a criminal act is someone's act because the act of a person is the cause and basis for giving offense." [3] This means that committing a criminal act should have an active character, so every muscle movement that is done deliberately by an individual has the aim of causing an effect. The first condition for the imposition of punishment is that someone has committed an act. The action referred to has fulfilled the formulation of the offense stated in the law. The second condition for imposing a criminal sanction against someone other than their actions has fulfilled the formulation of offenses that are listed in the law. Third, the requirements for the imposition of a crime against someone, namely that someone has no justification. The justification reason is the reason that eliminates the nature of the act against the law even though the act of someone who is against the law is in accordance with the provisions of the offense in the law, but if the act is not against the law then there is no punishment for him In addition to being reviewed based on the act, the conditions for punishment can be seen based on the condition of the person who committed the criminal act. ) In addition to being viewed from the act, the requirements of punishment look at the characteristics of the person who did the wrong. One of the characteristics of this person is the ability to take responsibility for their own mistakes. The ability to be responsible is a condition of the spirit of the perpetrator of a criminal act that justifies the application of an attempt at punishment both from a general point of view and also from the person, that a person is considered to have the ability to be responsible if he is sane. 


\subsubsection{Mandatory minimum sanctions theory}

Mandatory minimum sanctions is a criminal threat because there is a limit to the minimum sanction period with a time determined by the formulation of law.[4] Mandatory minimum sanctions only exists in certain laws outside the Criminal Code and is also contained in the draft RKUHP which will be ratified in the future. A mandatory minimum sanction is applied to offenses that are deemed to cause public anxiety and are also considered dangerous for society. ) Not all criminal laws outside the Criminal Code have mandatory minimum sanctions penalties, one of which is the Psychotropic Crime Law. The application of a mandatory minimum sanction can be a hope that makes it easier for judges to decide less severe cases because quite often there are differences in the verdicts of the same cases which are caused because there are things outside the legal facts that can affect the judge.

\subsubsection{Fundamental value of law theory}

To achieve legal objectives, Gustav Radbruch argued that it is necessary to apply the priority principle of 3 basic values which are the legal objectives. This is because in reality, legal justice always intersects with legal benefits and certainty and vice versa. Among the 3 basic values of legal objectives, at the time of contact, one of these basic values must be removed. For this reason, the principle of priority used by Gustav Radbruch must be carried out in the following order :

\subsubsection{Legal security}

Legal security is one of the objectives of law which can be said to be an effort to achieve justice. The real form of legal security is law enforcement of an action regardless of who did it. The existence of legal security in each individual can know what risks will be received if they take certain legal actions.[5] Certainty is useful for achieving the principle of equality before the law, namely the principle that all people are not viewed on the basis of race, ethnicity, class, status owned by a person. Certainty is closely related to the principle of truth. The principle of truth is something that can be concluded through legal logic. Through deductive logic, legislation is a major premise, while concrete events are a minor premise. Through a closed logic system will get the conclusion as it is. The conclusion must be something predictable, so that everyone is obliged to stick to it. This is the handle for society to become orderly. So, certainty will provide guidance for society towards order

\subsubsection{Legal utility}

Legal Utility or Utilitarinism was first developed by Jeremy Bentham. ) The problem faced by Bentham during his lifetime was how to judge whether a social, political, economic and legal policy was morally good or bad. It can be concluded that assessing a public policy has an impact on many people morally. Bentham found that the most objective basis is to pay attention to whether a certain policy or action can be useful or otherwise cause harm. When it is related to what is expressed by Bentham to the law, then the pros and cons of the law must be measured from the pros and cons of the consequences resulting from the application of the law.

\subsubsection{Legal justice}

Justice is an extension of the civilized order of society. The law is made so that every individual member of society and the state takes actions necessary to maintain social ties and achieve the goal of a common life or vice versa so as not to take action that can damage the order of justice. ) If the ordered action is not carried out or a prohibition is violated, the life of the community will be disturbed because justice is not achieved. To order social life, justice must be upheld. Every violation must be penalized according to the severity of the violation itself. According to John Rawls, the rules are made to achieve justice in order to benefit weak groups of society. The point is applied so that everyone has the same opportunity in life. In Rawls's view, all differences between people based on race, ethnicity, religion and other differences must be rejected.

Justice based on equality is based on the principle that the law is bound to all people, so that the justice that the law intends to achieve is understood in the context of equality. The similarities meant here consist of numerical equality and proportional equality.

\subsection{Our Contribution}

This research is expected to be useful for judges to repeat the actions of the judges in the Surabaya High Court Decision Number 763 / PID.SUS / 2020 / PT SBY because the panel of judges at the court handed down criminal decisions under mandatory minimum sanctions. because it can harm the honest panel of judges because the result of one person who does not carry out their duties properly, the judge's image in the views of the community becomes bad.

Structure of this paper consists of 3 parts.

a. The first part is an introduction.

b. The second part is a discussion

c. the third part is the conclusions and suggestions.

\subsection{Paper Structure}

The type of research used in this research is normative or doctrinal legal research. The research specification that will be used in this research is prescriptive research. The kind of data and data collection in this research is qualitative and literature study data. The research approach 
used is the laws approach and the case approach. The technique to analyze data is deductive by explain the major premises and minor premises in this research.

\section{BACKGROUND}

\subsection{Juvenile Justice System}

The juvenile justice system should be implemented to provide protection and equality between public order and children's interests so that it can be applied fairly and in a balanced manner. The juvenile justice system is oriented towards the application of special justice to someone who commits a crime against a child by paying more attention to the protection of children from a social, mental, and moral perspective than the concept of punishment.[6] Criminalization shown by the juvenile justice system is a process of moral and mental rehabilitation of children by paying attention to the best interests of the child, which is one of the principles of the Convention on the Rights of the Child which has been ratified in Article 2 of the Child Protection Law. Legal treatment of children deserves serious attention because children are the successor of the nation's generation. Because children are the successor of generations, judges in making decisions must consider whether the verdict is correct because the decision made by the judge will be able to become a strong basis for returning and managing children to become the successor of a good nation generation to grow and develop as members of a community responsible for the life of the nation.

\subsection{Convention on the Rights of the Child 1989 by United Nation}

Article 37 of the Convention on the Rights of the Child contains principles that states that are parties to the convention must guarantee:

First, Children must not be the target of abuse, or other cruel or inhuman treatment. Neither the death penalty nor life imprisonment allows release to take place shall be imposed for offenses committed by children under 18 years of age;

Second, Children should not be deprived of their freedom by violating the law or arbitrarily. The detention, arrest or imprisonment of a child is required by law, and shall be used only as a last resort and if carried out must be enforced within the shortest appropriate period of time;

Third, every child who is deprived of his freedom must receive humane treatment and respect for inherent human dignity, and in a way and receive the needs according to his age. In addition, children who are deprived of their liberty must be separated from adults unless this is done because it is in the child's interest and must have the right to continue to have a relationship with the family both through correspondence and visits.
Fourth, every child who is deprived of his liberty has the right to have access to legal and other assistance appropriately, and the right to deny the truth of his deprivation of liberty, before a court or other competent authority, just and independently, and to an immediate judgment regarding any such action.

Based on the description of the principles of protection of criminal law against children, which comes from Article 37 of the Convention on the Rights of the Child, the article makers can evaluate how the rights of children as weak parties receive special protection that must be upheld so that they have the spirit of life and trust. themselves again optimally to grow and develop in order to become the nation's next generation.[7]

\subsection{Criminal Justice System}

The concept of the criminal justice system known in Indonesia is a condition in which institutional and functional relationships are established, namely coordination between the various subsystems with each other according to their respective roles and authorities as well as functions and authorities regulated in criminal procedural law in order to enforce the law applicable criminal law. This means that the criminal justice system begins with the process of investigation, then prosecution, then examination at trial until finally the implementation of the judge's decision.

Judges have very broad freedom to determine the type of crime according to their wishes, because in the principle of positive criminal law Indonesia uses an alternative system in determining criminal sanctions. However, the mandatory minimum sanctions system limits the opportunity for judges to use the principle of freedom in imposing crimes. In the development of the formulation of laws and regulations, there are now several laws that contain a mandatory minimum sanctions system where regulations are outside the Criminal Code, such as those contained in Law Number 35 of 2014 concerning Child Protection. The existence of a mandatory minimum sanctions system can limit the freedom that judges have in making decisions.

\subsection{Mandatory Minimum Sanctions System}

The mandatory minimum sanctions system contained in Law Number 35 of 2014 concerning Child Protection is expected for perpetrators of criminal acts against children to be subject to severe penalties, this is because every year the number of perpetrators of crimes against children increases, one of the causes is a decision handed down by a minor judge means that the imposition of punishment does not cause a deterrent effect for the perpetrators of criminal acts against children. In fact, this action can cause the child's condition to grow and develop to be bad due to disturbances in mental, physical and social life to live the childhood, thus endangering the future generations of the Indonesian nation.[8] 


\subsection{Stages of Law Making in Indonesia}

The first stage is formulation stage. Formulation stage is the stage of determining a mandatory minimum sanctions law which contains various types of actions that can be applied to a specific minimum punishment and what types of sanctions are appropriate to limit the imposition of the sanction, the power that is authorized to carry out this stage is the legislative power. The legislature in Indonesia consists of the DPR and DPD.

The second stage is application stage. Application stage is the stage of determining a mandatory minimum sanctions law by imposing a sanction on a person by a judge for an act committed by that person must be decided on mandatory minimum sanctions. The authorized party at this stage is the Judicial power. The judiciary in Indonesia consists of the Supreme Court and the Constitutional Court.

The third stage is execution stage, which is the stage of carrying out a crime by the officers of criminal execution for the perpetrator of a serious crime who has been sanctiond to a mandatory minimum sanction. The authority in this case rests with the Executive power. The executive in Indonesia is held by the President.[9]

\section{DISCUSSION}

Mandatory minimum sanctions is also applied by the legislative body to prevent the imposition of light criminal sanctions for serious crimes. This is because the mandatory minimum sanctions can limit the judge in verifying the defendant who violates the offense with mandatory minimum sanctions. [10]

This is indicated by an offense containing the phrase "the least" or "the shortest". The judge cannot issue a criminal verdict with an amount less than the "least" stipulation on the offense. The judge as a judicial legal entity has the authority to impose criminal sanctions on a defendant who has committed a criminal act. In imposing criminal sanctions, judges basically have the principle of freedom, namely the judge is free to impose decisions based on his beliefs. Mandatory minimum sanctions is an exception as one of the provisions that can limit the principle of freedom of judges.

Several judges in Indonesia have not implemented the mandatory minimum sanctions sanctions properly. For example, in the Surabaya High Court Decision Number 763 / Pid.Sus / 2020 / PT Sby. The defendant in this case Ali Shodiqin committed a criminal act of sexual abuse against a child. Based on the indictment, the Public Prosecutor Ali Shodiqin has been proven to have violated the provisions of Article 82 of Law Number 35 Year 2014 concerning Child Protection.

Article 82 of the Child Protection Law states that every person who commits violence or threats of violence, coerces, commits trickery, commits a series of lies, or persuades a child to commit or allow obscene acts to be subjected to imprisonment for a minimum of 5 years and a maximum of 15 years.
In fact, the judge at the Surabaya High Court gave a verdict in the form of 10 months in prison. It can be concluded that the judge has violated the mandatory minimum sanctions provisions. The minimum verdict should be 5 years.

Legal policies made by the legislature with the existence of mandatory minimum sanctions provisions in article 82 of Law Number 35 of 2014 concerning Child Protection are of no benefit. Defendant Ali Shodiqin should have received heavy sanctions but because the judge at the Surabaya High Court did not apply mandatory minimum sanctions provisions, the sanctions were not severe.

The application of proper sanctions in the High Court Decision Number 763 / Pid.Sus / 2020 / PT Sby is more than 5 years. This is because the mandatory minimum sanctions provisions prohibit judges from verifying less than 5 years.

Because the purpose of a mandatory minimum sanctions when viewed from legal policy is to give fear to the perpetrator of the crime. In addition, judges must also consider whether the defendant is appropriate or not to be subject to criminal sanctions. Because the imposition of criminal sanctions or punishment has conditions that must be met.

The facts from the position case in the Surabaya High Court decision Number 763 / Pid.Sus / 2020 / PT Sby stated that Ali Shodiqin was proven to have committed sexual abuse against a child. This is because based on a psychologist's examination of 20 children at Labschool Ketintang Middle School, there were 4 victims of sexual harassment from Ali Shodiqin. [11]

The four victims were proven legally treated to receive sexual harassment from Ali Shodiqin based on the evidence available when the trial took place.

In the case in the Surabaya High Court Decision Number 763 / Pid.Sus / 2020 / PT Sby, the actions of the accused Ali Shodiqin have met the formulation of the Law.

The actions of the defendant Ali Shodiqin who had committed the criminal act of sexual immorality against several students at the Ketintang Lab School Middle School were regulated in article 82 of Law Number 35 Year 2014 concerning Child Protection which contained "Everyone who commits violence or threatens violence, coerces, commits tricks., commits a series of lies, or persuades a child to commit or allow obscene acts to be committed, shall be punished with a minimum imprisonment of 5 years and a maximum of 15 years.

Defendant Ali Shodiqin based on the evidence submitted in the Surabaya High Court process Number 763 / Pid.Sus / 2020 / PT Sby has been proven to have committed a criminal act of sexual immorality.

This evidence was found based on psychological examinations on a number of 20 students at the SMP Lab School Surabaya. The results of the psychological examinations of several children revealed the fact that Ali Shodiqin had indeed committed the crime of sexual immorality against several children at the Ketintang Middle School Lab.

In article 82 of the Child Protection Law, there are elements of action that can ensnare the perpetrator of a 
criminal act, namely the defendant committing violence or threats of violence forcibly or tricking the victim, committing a series of lies, or persuading a child to commit or allow obscene acts to be committed.

Based on the testimony in court at the Surabaya High Court, the defendant was proven to have committed forceful violence as a teacher of the students who had become victims. The students of SMP Labschool Ketintang felt threatened because the defendant's position was high, namely as a teacher and school principal. The actions of the defendant Ali Shodiqin also fulfilled the formulation of article 82, namely that the object of the crime committed by the defendant was a child. Based on article 1 number 1 of Law Number 35 Year 2014 concerning Child Protection, a child is someone who is not yet 18 years old.

The victims of the criminal acts committed by Ali Shodiqin were students of the Ketintang Labschool Middle School who were 14 years old. It can be concluded that from the ages of children who are victims of the criminal act of sexual immorality by Ali Shodiqin, they have fulfilled article 82 of Law Number 35 of 2014 concerning Child Protection. The actions of the defendant Ali Shodiqin were also classified as obscene acts. Article 82 of Law Number 35 of 2014 concerning Child Protection can be imposed against the perpetrator of the crime of child molestation.

R. Soesilo stated that obscene acts according to the Criminal Code are all acts that violate decency as well as politeness or heinous acts committed due to sexual lust from the perpetrator of the crime himself. Based on the testimony in the trial it was proven that Ali Shodiqin often committed crimes of sexual immorality against students who had been victims. One of the actions of the defendant was groping the victim's genitals forcibly. [12]

The criminal act of child molestation committed by the defendant Ali Shodiqin deserves to be sanctiond to punishment under Law Number 35 of 2014 concerning Child Protection. The use of special criminal rules is prioritized in this case because the Criminal Code does not regulate the imposition of sanctions against perpetrators of criminal acts against children. The legal vacuum contained in the Criminal Code has led the Public Prosecutor to indict Ali Shodiqin in the form of an offense in Law Number 35 of 2014 concerning Child Protection.

In the Convention on the Rights of the Child held by the United Nations in 1989, States Parties promised to provide protection for children from all forms of sexual exploitation and sexual abuse. To this end, States Parties in particular will take appropriate steps, one of which is severe sanctions.

This form of serious sanction is a mandatory minimum sanctions sanction. Sexual exploitation and sexual harassment as referred to in article 34 of the Convention on the Rights of the Child include:

First, Seducing or coercing a child into engaging in any illegal sexual activity;

Second, The exploitative use of children in prostitution or other illegal sexual practices;
Third, The exploitative use of children in pornographic shows and materials.

If it is related to legal security in the settlement of cases of juvenile crime, it turns out that Indonesia is one of the countries that is a party to the convention.

This concludes that criminal cases against children must be resolved at the court table. [13]

Various attempts were made to find a way of peace from the perpetrator to the victim's party, which in this way could serve as a sociological basis for the application of a mandatory minimum sanctions in the Child Protection Law itself. With the existence of peaceful efforts, the creation of security and order in any aspect will become neater and tidier and ensure the safety and tranquility of society from acts of revenge which have implications for all problems of life. [14]

Early crime prevention is able to protect the community from the recurrence of a crime that can disturb people's lives. It is unfortunate if the trial process of crimes against children still contains errors in the imposition of crimes that are not in accordance with the mandatory minimum sanction provisions.

The aspect of legal security is to emphasize that the law or regulation is enforced as written in the sound of the law / legislation. Because this case was decided by the judge on June 4, 2020, it is unfortunate if the criminal justice process against children still violates the mandatory minimum sanctions provisions.

\section{CONCLUSION}

According to article 82 of the Child Protection Law, it has been stated that every person who commits a criminal act of sexual immorality against a child will be subject to sanctions in the form of imprisonment of at least 5 years and a maximum of 15 years.

It can be concluded that Article 82 of the Child Protection Law contains mandatory minimum sanctions provisions marked with the phrase "least" in the offense. In fact, in the decision of the Surabaya High Court Number 763 / Pid.Sus / 2020 / PT SBY did not make a decision based on the mandatory minimum sanction provisions written in article 82 of the Child Protection Law because the panel of judges gave a verdict on the defendant Ali Shodiqin with a penalty of 10 months in prison.

Less than the minimum number of sanctions from that article. This shows that the panel of judges at the Surabaya High Court Number 763 / Pid.Sus / 2020 / PT SBY does not apply the principle of legal security. The principle of legal security states that the law must be carried out according to what is written in the Law.

The Panel of Judges at the Surabaya High Court Decision Number 763 / Pid.Sus / 2020 / PT SBY as the body authorized to make decisions should implement the mandatory minimum sanctions provisions contained in article 82 of Law Number 35 of 2014 concerning Child Protection.

Judges as legal entities have the principle of freedom, namely judges are free to make decisions based on their 
convictions, but there are exceptions to the judge's freedom.

Mandatory minimum sanctions is an exception as one of the provisions which limits the principle of freedom of judges. The step that should have been taken by the panel of judges was to issue a verdict on the accused Ali Shodiqin in the form of imprisonment of more than 5 years. Judges This also applies to all judges who serve in Indonesia so that they can carry out their duties and powers properly.

Good judicial power is one of the conditions that can make people believe in the law in Indonesia.

\section{ACKNOWLEDGMENT}

This work is supported by the International Conference on Economics, Business, Social, and Humanities (ICEBSH), Faculty of Law, Tarumanagara University, Jakarta, Indonesia

\section{REFERENCES}

[1] Barda N. Arief, Bunga Rampai Kebijakan hukum Pidana. (Bandung: Citra Aditya Bakti, 2002), pp. 128

[2] M. Gultom, Perlindungan Hukum Terhadap Anak dan Perempuan, (Bandung: Refika Aditama, 2018), pp. 23

[3] Sudarto, Hukum Pidana, (Semarang: Yayasan Sudarto, 2018), pp. 70

[4] Barda N. Arief, Bunga Rampai Kebijakan Hukum Pidana, (Jakarta: Kencana Prenada Media Group, 2016) pp. 80

[5] S. Soekanto \& S. Mamudji, Penelitian Hukum Normatif, (Jakarta: Raja Grafindo Persada, 2013), pp. 13

[6] S. Soekanto, Pengantar Penelitian Hukum Universitas Indonesia, (Jakarta: Raja Grafindo, 2014) pp. 15.

[7] Peter M. Marzuki, Penelitian Hukum, (Jakarta: Kencana Prenada Media Group, 2013), pp. 181

[8] M. Mahfud MD, Politik Hukum di Indonesia, (Jakarta: PT Raja Grafindo Persada, 2015), pp. 5

[9] H. Packer, Limits of Criminal Sanction, (Palo Alto: Stanford Press, 2012), pp. 21
[10] E.O. Hiariej, Prinsip-prinsip Hukum Pidana, (Yogyakarta: Cahaya Atma Pustaka, 2016), pp. 43

[11] M. Maurer, "The Impact of Mandatory Minimum Penalties in Federal Sentencing”, Judicature, Vol. 94, No. 1, Agustus 2010, pp. 6

[12] Z. Arifin, Kekuasaan Kehakiman di Indonesia, (Malang: Setara Press, 2016), pp. 81

[13] S. Rahardjo, Ilmu Hukum, (Bandung: PT Citra Aditya Bakti, 2014), pp. 19

[14] S. Mertokusumo, Mengenal Hukum, (Yogyakarta: Liberty Press, 2019), pp. 56. 